\title{
Would Lower Federal Deficits Increase U.S. Farm Exports?
}

\author{
MichaeI T. Belongia and Courtenay C. Stone
}

ANY fam policy experts believe that U.S. agricultural exports would be increased significantly if federal budget deficits were reduced. One such expert, for example, has commented that "a more nearly balanced federal budget probably would do as much as anything to improve our agricultural export performance." Other analysts also have predicted that the farm ontlook will remain bleak until this nation develops "a chedible plan to leduce the enormous Federal budget deficits." "This view is so pervasive that it might now be considered the conventional wisdom on the subject."

If this view is valid, it has important implications for domestic farm policy legislation, including the pending farm bill: If federal budget deficits have setrously reduced farm exports and, consequently, seal farm income, then legislators should focus primarily on reducing the deficit to revive farm exponts and income; in this case, current commodity programs may need little fundamental change once the deficit has been reduced. If budget deficis have not contributed materially to the decline in farm exports, however, then focusing attention on deficit reduction measures may

Michael T. Belongia and Courtenay C. Stone are senior economists at the Federal Reserve Bank of St. Louis. David J. Flanagan provided research assistance.

Schuh (1984), p. 246.

2Duncan and Drabenstott (1985)

"Of course, this view is not confined solely to farm policy experts. It is held by a large number, perhaps even the vast majority, of policy analysts. For simitar statements about the effect of deficits on exports, see Clark (1985), Downs (1985), Kraft (1985) and Modigliani (1985)

The omnibus farm legisiation currently in effect is a four-year bill that was passed in 1981. Congress is now debating the issues encompassed by a new four-year bill, renewal of existing legislation, or returning to the "permanent" legislation of the 1930 s and 1940 s that covers most major commodities. divert attention from more fundamental changes that might be required in farm commodity programs. The purpose of this article is to describe the theoretical links between fedeal budget deficits and U.S. fam exports and to examine the empirical evidence on these links.

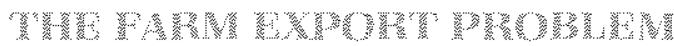

singled out as a strong, pethaps the ptimary, suspect in attempts to explain why farm exports have declined so sharply in recent years. A prima facie case can be made for the deficit explanation by simply looking at the recent relationship between exports and the deficit this comparison is shown in chan 1 for semiannual data since 1973 .

If we look only at the past four vears, we see that nominal fam exports declined fiom 1981 though 1983, rose marginally last year, and have fallen again through early 1985. During this same period, federal deficits, as measured by the national income accounts, skyrocketed, rising from $\$ 64$ billion in 1981 to $\$ 176$ billion in 1984 . The association between rising deficits and falling exports appears to be obvious.

Yet when the entire period is examined, this conchusion is not so obvious. Deficits were rising and falling from 1973 when it was only $\$ 6$ billion to 1981 . This period was one of generally ising farm exports. Thus, the view that rising deficits adversely affect exports is one that seems to be based primarily on evidence from the most recent period. Such a narow focus necessarily raises questions about the generality of the presumed relationship and the likely effect of policies designed to exploit the relationship.

To get a better perspective on the relationship between deficits and farm exports, we must focus on the 


\section{Chart 1}

\section{Deficit and Farm Exports}

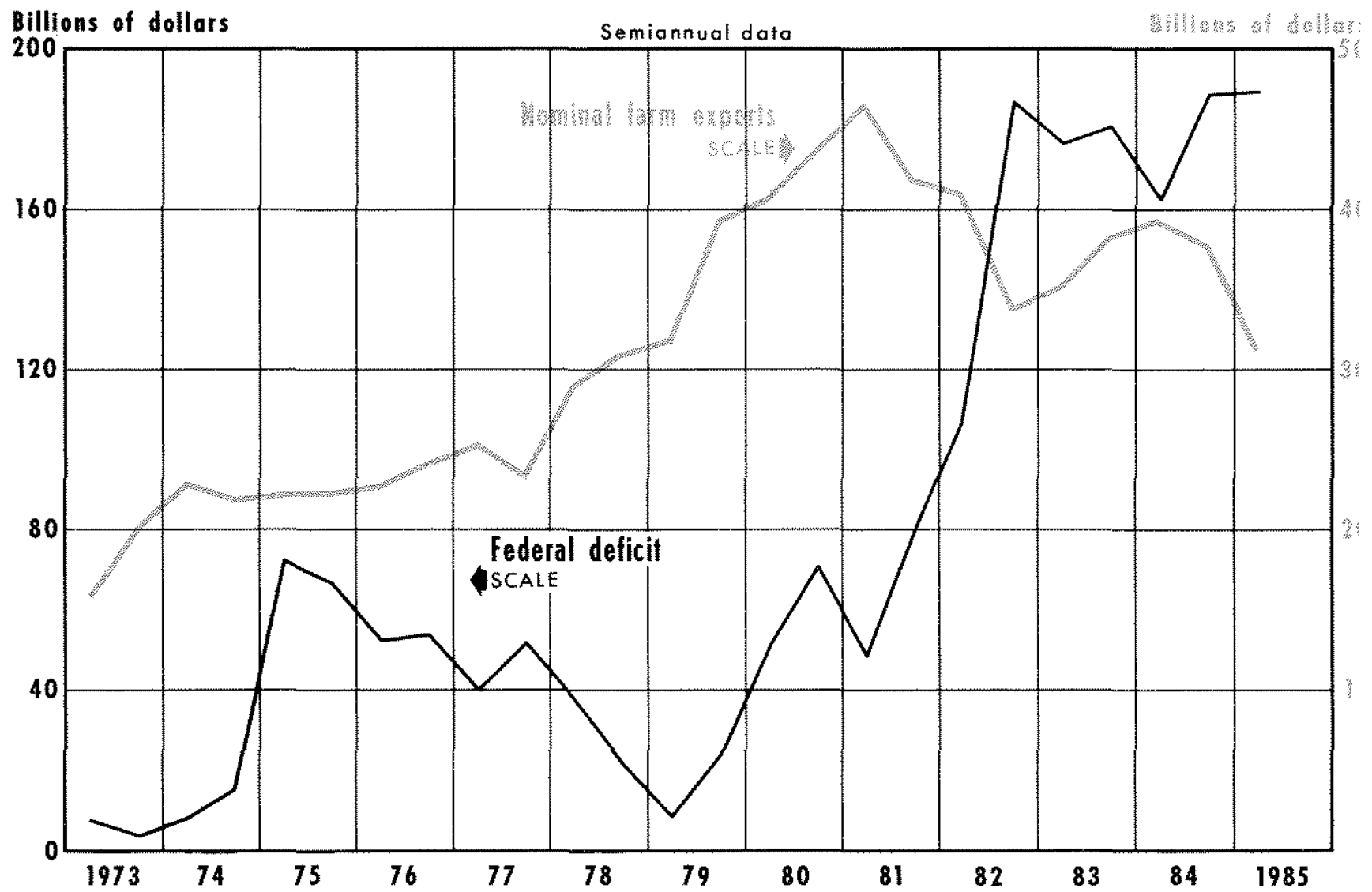

theoretical relationships that the them together and the empirical support for these underying theories.

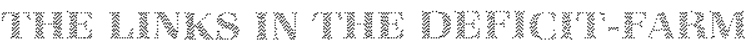

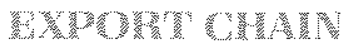

The conventional view of the links between deficits and farm exports is shown in figure 1 . In this framework, the problems of reduced exports, expanded imports and political measures promoting protection for domestic industries can be traced backward, stepby-step, to their source: large, pexsistent federal budget deficits. An examination of figume I shows that there ae at least three key economic relationships that must exist for this conventional view to be valid.

First other things unchanged, deficts must be related svstematicaly to real interest rates interestales adjusted for expected inflation): specifically, highe deficits must raise real interest wates and lower deficit must reduce them. Second, real interest rates must b related systematically to the real foreign exchang value of the dollar the dollar's value after adjusting to differences in inflation between the United States ar foreign countries/; highed real fates must raise th dollar's real value and lower real rates must reduce if Third, the real foreign exchange value of the dolla must be related systematically to real agricultural ex ports tagricultural export receipts adjusted for move ments in the general price level, higher real exchang rates must reduce real fam exports and lower ex change rates must increase them. The conclusion the

More correctly, the second link tefers to the impact of higher re interest rates in the United States vis-a-vis those in other countrie This is explained tater in this article. 


\section{Figure 1}

\section{A Schematic View of The Theoretical Linkages Between Deficits and Farm Exports}

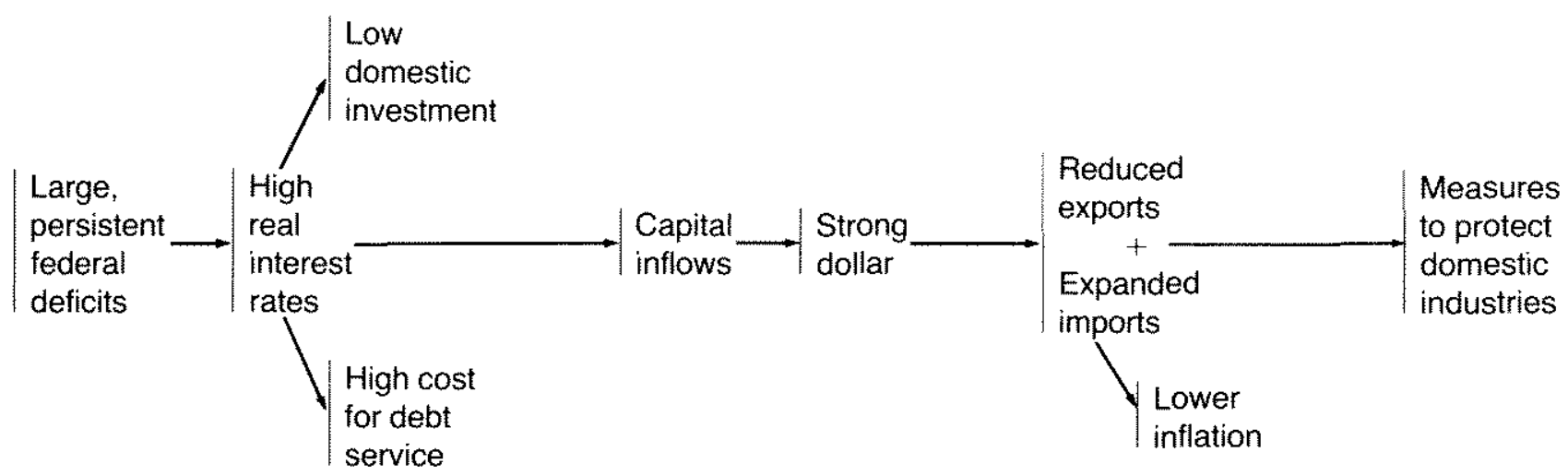

SOURCE: Dobson (1984), p. 49.

lower federal deficits will increase fam exports by reducing real rates of interest and, thus, the real foreign exchange rate of the dollar, relies on the validity of these links. We analyze these links in turn in the following sections,

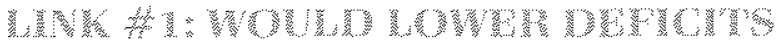

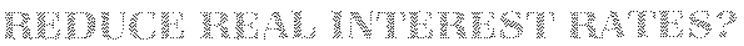

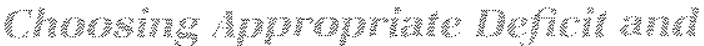

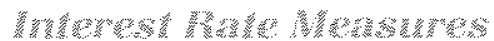

One basic problem with trying to discern the relationship between deficits and interest rates is that the measures we observe must be "adjusted," both to eliminate potentially confounding influences and to focas the analysis on those measures that ane emphasized by the underlying economic theory. The deficit measure can be adjusted in a variety of ways. Three commonly used procedures are: 11 to adjust for the impact of inflation by using a real deficil measure; 12 to adjust for the size of the economy by dividing the deficit by some measure of spending or saving; and is to remove the business cycle influences on the deficit.

Interest rates also must be adjusted approprately if we are to capture the deficit's influence on them. Maket interest rates - the ones that we see quoted every day - can be thought of as the sum of two basic components: the expected inflation rate and the expected lor ex antel real rate of interest changes in the deficit per se should have no effect on the expected rate of inflation unless the Federal Reserve is expected to monetize the deficit that is, increase its purchases of government bonds! ' Since changes in the expected rate of inflation, however, cause nominal interest rates to change and obscure the impact of changes in the deficit, we must remove the influence of changes in inflation expectations; we must focus on the deficit's impact on the expected real rate of interest.

\section{The Con

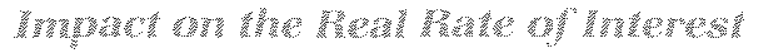

The view that larger deficits increase the expected real rate of interest is based on the validity of the "interest-rate crowding out" phenomenon. Interestrate crowding out is demonstrated graphicaly in

\footnotetext{
6 For discussions of the differences between nominal and real interest rates and between ex ante and ex post interest rate measures, see Santoni and Stone (1981a, $198 \mathrm{tb}$ and 1982); for an analysis of the problems associated with attempts to measure real interest rates, see Brown and Santoni (1981).

${ }^{7}$ For evidence that larger deficits per se are not associated with faster inflation, see Protopapadakis and Siegel (1984) and Weintraub (1981).
} 
figure 2 , which depicts the demand for and supply of real resources allocated though credit markets. The demand curve, labeled $D_{\text {s }}$ is the demand for resources by would-be borrowers: consumers, private firms and, of course, the govemment. The supply curve, labeled $\mathrm{S}$, represents the amount of cument saving that wouldbe lenders (savers) are willing to provide. The price that infuences these borrowing and lending decisions separately, and that is determined jointly by the interactions of all borrowers and lenders, is the real rate of interest.

Using figure 2, it is easy to show how a larger deficit could increase the real rate of interest. If all other things remain the same, a larger deficit increases the demand in the credit maket to $D^{r}$ and results in a higher price of credit as the real rate of interest rises to $r_{E}$. The additional resources that the govenment obtains come partly from additional saving for example, people reduce their consumption and partly from reductions in non-government borrowing (for example, private investment declinesl. The larger deficit and the resulting higher real interest rate have thus crowded out, or reduced, private sector consumption and investment.

Of course, the extent to which the real rate of inter' est actually inceases under the conventional view depends on the specific slopes of the demand and supply curves; the flatter are the demand and supply curves, the smaller the rise in the real rate of interest.

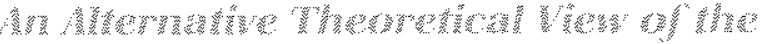

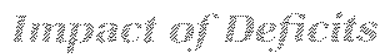

Interest-rate crowding out, as depicted in figure 2 , is predicated on the view that increases in the deficit per se have little effect on the supply of or the demand for credit by consumers and private fims. Instead, consumers and private firms respond by moving along their unchanged demand and supply curves in response to changes in the real rate of interest produced by the increased government deficit.

An alternative view of how people respond to changes in government deficils suggests that the real rate of interest is essentially unaffected by government deficits. This view states that people see deficits as

8This view has been popttarized by Barro (1974) and Seater (1982), among others. For a recent discussion of the conventional and alternative theoretical relationships between deficiss and interest rates, see Rasche (1985) and Tatom (1985); for recent evidence supporting this alternative view, see Kormendi (1983) and Protopapadakis and Siegel (1984).

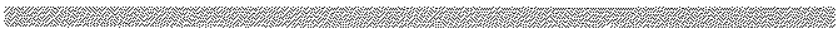

Figure 2

\section{Comparison of Defietit's Impact on Interest Rates}

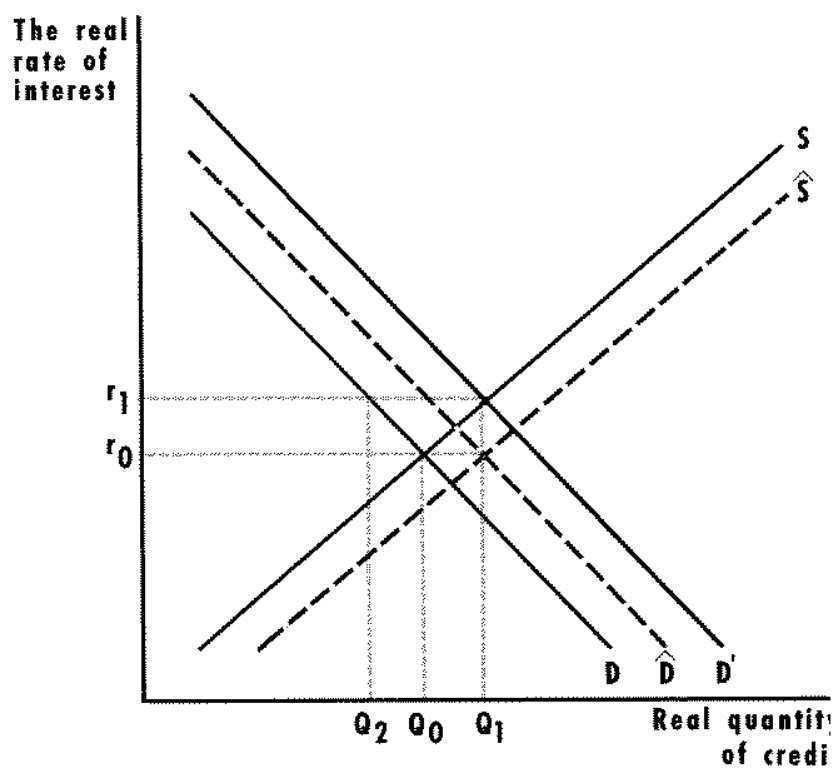

等

implied taxes that eventually must be imposed on their future incomes to repay the larger governmen obligations. Thus, larger deficits today are equater with larger future taxes and reduced future after-fa: incomes. As a result, an increase in the deficit reduce people's permanent incomes; this, in tum, reduce the private and, thus, the total demand for credit at $\hat{D}$ i, while increasing private saving and, thus, the sup ply of credit $(t) \hat{S i}$. As shown in figure 2 , although defi cits crowd out private investment and consumption they have no appreciable impact on the real rate 0 interest, which remains unchanged at $r_{t 1}$. Th. crowding-out is direct; it does not take place througl increased real interest rales.

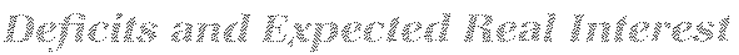

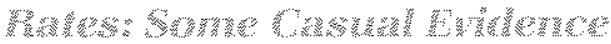

The conventional view suggests that other thing the same, laryer deficits are associated with highe expected real interest rates; the alternative view sug gests that they are not.

Chart 2 displays the behavior of one adjusted defict measure and one measure of the expected real inter est rate that, according to conventional theory, is in fluenced by federal deficits. The deficit measure use is the real cyclically adjusted deficit divided by poten 
Chart 2

\section{Deficit and Ex Ante Real Interest Rate}

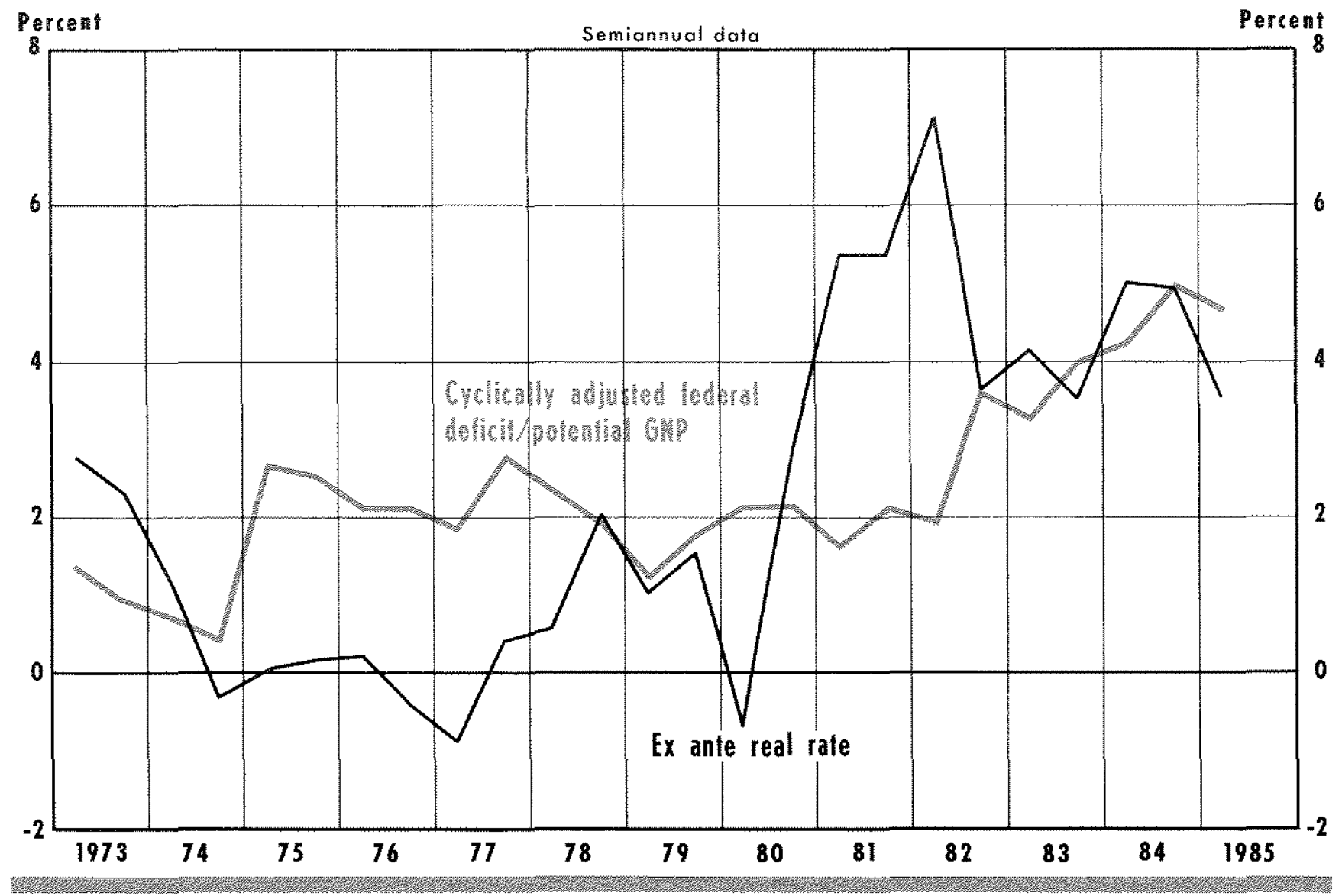

tial real gross national product (GNP)." The expected real interest rate measure is obtained by subtracting six-month inflation forecasts from six-month interest rates at the time the inflation forecasts were made."

An examination of chant 2 provides some evidence that the real interest rate does not respond to changes in the federal deficit th the way that is generally expected. for example, average ex ante real interes rates were much higher in $1973-74$ than they were in $1975-$ 77 , even though the fedeal deficit measure was about

${ }^{3}$ For discussion of the rationale and use of cyclically adjusted deficit measures, see Tatom (1984); for discussion of the impact of recent recessions on deficits, see Malabre (1985).

10The ex ante real interest rate series was constructed by the following method: six-month-ahead inflation forecasts for the consumer price index (CPI) were derived from the Livingston survey data. These expected inflation figures were then subtracted from the quarterly averages for the six-month Treasury bili rate for the quarters in which the surveys were taken. For more details on this method, see Holland (1984), twice as high in the later veass than if was in the earlier vears. Similarly, the expected real rate rose spectacu latly from early 1980 to ealy 1982 when the deficit measure was virtually unchanged; since then, the real rate has declined considerably, vet the deficit has climbed substantially.

Chart 3 summarizes the relationship between the deficit and the real interest rate in an altemative fashion. It is a scatter-diagam of the associated changes in the defict and ex ante real interest fate measures. If increases idecreases in the deficit generally were associated with increases decreasesi in real interest rates, then the vast majority of the associated pairs of deficit-interest rate changes would be in the first II and thind (III quadrants of the chant. As a perusal of chart 3 indicates, however, the points are scaltered faily randomly with half of them in the "wrong" parts of the chart.

The solid line, labeled $R$, is the regression line 
Chorf 3

Changes in Deficit and Ex Ante Real Interest Rate

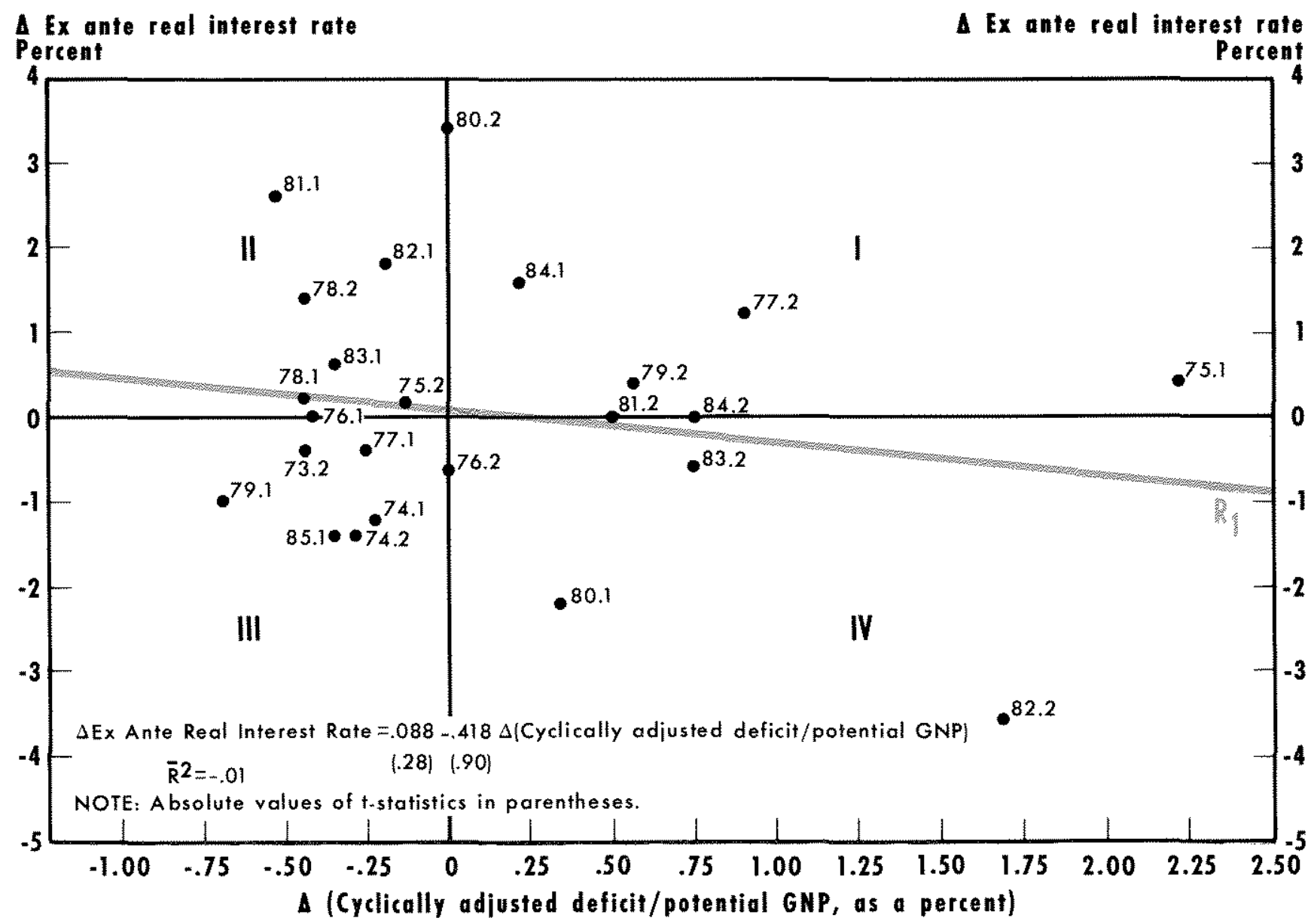

showing the estimated linear relationship between changes in the deficit measure and changes in the expected real rate of interest. The conventional theory suggests that the line should slope upward fom leti to right in chant 3 ; in fact it does not. The slope, however, is not statistically significant. Thus, a simple analysis suggests that changes in the deficit have no significant effect on movements in the real wate of interest.

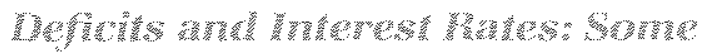

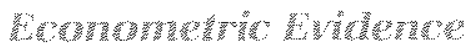

Charts 2 and 3 are not intended to demonstrate that deficits have no effects on real ineres rates: they do show that there is no easily discemible relationship between them. Because a host of other influevees could have confounding effects on such a simple comparison, more detailed econometric analysis is required to decipher the impact of deficits on interesi rates.

Infortunately, such analyses generally have not been able to isolate the effects of deficits on real interest rates or draw any firm conclusions. Table 1 which contains a summary of stach studies, shows evidence that is highly ambiguous. "While some studies found positive impacts of deficits on inferest rates other studies found mixed or even negative effects while the effects were statisticaly significant in some studies, they were insignificant in others. Anothes summary of such studies reported simblar findings.:

"See Congress (1984), p. 100

:U.S. Depatment of the Treasury (1984). 
Table 1

Federal Deficits and Interest Rates: Some Empirical Findings

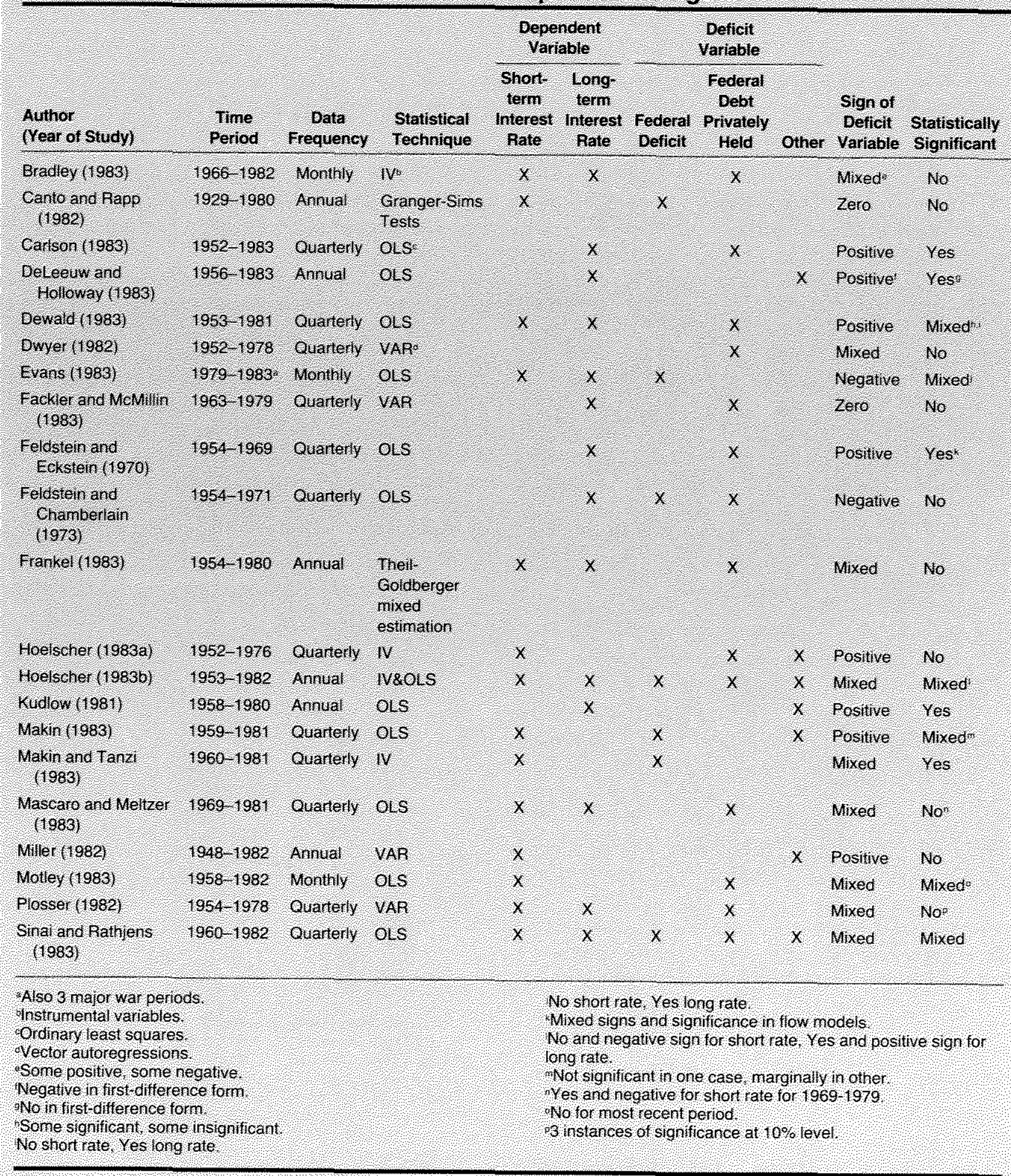

SOURCE The Economic Ouflook f February 984, Congressional Budget Otice Simulation reterences were deleted 
Thus, it appears that econonetric studies provide only weak evidence to support the view that federal deficits have a significant influence on interest tates."

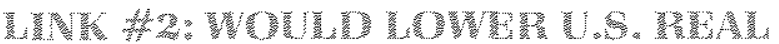

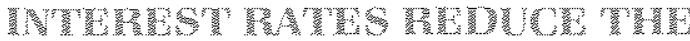

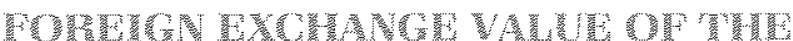

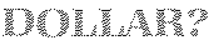

Most farm commodities traded in international markets are priced in U.S. dollars regardess of where they are produced. Consequently, a set of events that raised the value of the dollar in tems of Brazilian cruzeiros, for example, would make Brazilian soybeans less expensive than U.S. soybeans. Nations that import soybeans could use their dollars to purchase cruzeiros and, hence, purchase Brazilian soybeans more cheaply than before. Because of this relationship, changes in farm exports are linked to changes in the value of the dollar.

While we typically think of the value of the dollar visa-vis one or another specinc country's curency - for example, the Japanese yen, the French franc of the West German mark - such bilateral exchange rates by themselves, do not provide a clear picture of what is happening to the overall value of the dollar in foreign exchange matkets. Instead an index of the clollar's value often is used to incorporate information abozt the movement of the dolla relative to other majo: currencies. One index, called the lrade-weighted exchange rate of the U.S. dollar enables us to determine what is happening to the dollar's value relative to the currencies of our major trading partmers."

The foreign exchange value of the dollar is the relative price of the U.S. dollar in tems of other na tions currencies. The actual value of the dollar at any time is determined by the factors that underlie the demand for and stpply of dollas in fomeign exchange markets.

There currently is some controversy over which factors detemine exchange rates and the relative influences they have on exchange rate movements at

\footnotetext{
3For a detalled discussion of the major problems associated with empirical estimation of the deftcit's impact on interest rates, see Congress (1985a), pp. 77-84.

${ }^{14}$ The trade-weighted exchange rate used in this study is the Federal Reserve Board index (March 1973 $\approx 100$ ) of the weighted-average exchange value of the U.S. dollar against the currencies of other $\mathrm{G}$ 10 countres plus Swizerland. Weights are the $1972-76$ average total trade shares of each of the 10 countries.
}

any particular moment. "Thene is, however, a farly general analvtical framework that suggests four factors as the main influences on the behavior of exchange rates: 1) differences in inflation rates between comntries; 121 differences in ieal interest rates between countries; (3) differences in real economic conditions that influence trate patems; and if differences in political and other risks associated with invesment in specific countries." We focus on the effects of changes in the first wo factors on exchange mate movements. Unfortunately, changes in the remaining two factors can make it diffcult to decipher the actual impacts of changes in intlation and real interest rate differentials on the exchange rate at any given moment.

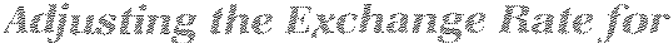

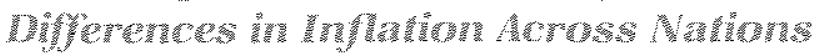

Theoretical considerations suggest that changes in bilateral and trade-weighted foreign exchange values of the dollat are inversely related to differences bem ween U.S. and foreign inflation rates. If this inflation differential (U.S. minus foreigr) is positive, the value of the dollar will decline over time: if the intlation differential is negative, the dollar's foreign exchange value will rise.

This felationshp called purchasing power parity, is based on the notion that simila goods taded in world markets must command stmila prices, regardess of where they are bought and sold. for oxample if a bushel of com costs $\$ 1,50$ in the United States and $E 3$ in the United Kingdom, an exchange tate of $\$ 2$ per dollar would "equalize" the price of l. S and U.K. corn to all purchasers. If inflation in the United stales drove the price of con to $\$ 3$ per bushel, then, other things the same, the exchange rate would have to fall to $\$ 1$ per dollar to bring the price of U.S. cort back in line with U.K. conn in wortd markets.

Of course, if changes in the value of the dollar were simply the result of changes in these inflation differen-

\footnotetext{
1For exampte, one analyst has noted that "there is no consensus on how exchange rates are determined. The interpretations vary widely among the various theories, fanging from the traditional approach of trade-oriented demand and supply factors, to the modern approach of asset-market mechanism and expectations. The analysis of currency determination is complicated by the interdependence of the exchange rates, monetary and other economic polictes, ard factors affecting economic and financial performance." Poniachek (1983) p. 2.3.3.

This discusston is based on the framework developed in Isard (1980).
} 
tials, exchange rate movements would be neutral with respect to trade patterns. Indeed, other things un changed, exchange late movements consistent with purchasing power parity will preserve cutrent trade patterns.

Exchange rates are affected by other factors, how ever, so that their movements are not consistent solely with purchasing power parity conditions. If exchange rates rise more for fall less than intation differentials warant, prices of U.S goods will rise relative to similar goods sold by other countries; if exchange rates rise less tor fall more than inflation differentials wamant, paices of U.S. goods will fall relative to foreignproduced goods.

This discussion suggests that, if we want to assess the effect of exchange rate movements on exports in general and farm products in particular, we should look at the movement in exchange rates after adjusting for the elfects of inflation differentials. One such exchange late measure is called the real trade-weighted exchange ate for the U.S dollar."

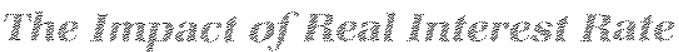

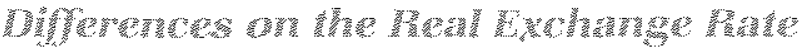

Theoretical considerations suggest that changes in the real tradeweighted exchange rate should be positively related to changes in the real interest late differential U.S. minus foreign If U.S. real interest mates rise relative to foreign real lates, othe things the same, the real trade-weighted value of the dollar should rise; if U.S. real interest males fall relative to foreign real rates, the real trade-weighted value of the dollar should decline. The presumption is that a positive real rate differential will attract foreign capital, while a negative differential will make investment abroad more attrac tive. Thus, changes in the real ate differential should cause similar changes in the reat rade-weighted exchange rate.

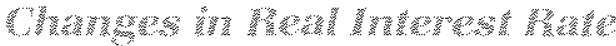

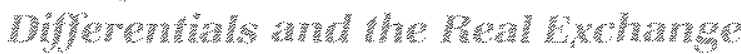 Prack}

Chart 4 shows what has hapened to the real tradeweighted exchange rate and one measure of the ex-

\footnotetext{
17The real trade-weighted exchange rate is the nominal tradeweighted exchange rate described earlier (see footnote 14) divided by the ratio of the U.S. consumer price index (CPI) to the foreign. trade-weighted CPl, each indexed to March 1973.
}

pected real interest rate differential IU.S. minus foreign expected real interest mates from 1973 to the present . " These data suggest that the link between the leal interest rate and the real exchange fate is not especially reliable. For example, average real interest rate differentials were approximately the same in the $1975-$ 78 and $1982-85$ periods, vel the real exchange rate was falling in the former period and rising in the latter one.

Chart 5 shows a somewhat different way of looking at the relationship between movements in the real interest differential and movements in the real exchange rate. It is a scatter-digram of changes in the real interest rate differential and the associated percent changes in the real exchange rate. Other things unchanged, economic theory predicts that the points should lie predominantly in the first $\mid 1 /$ and third $[111$ quadrants: positive (negative changes in the real interest rate differential should be associated with positive (negative) percent changes in the real exchange rate. This is not the case: the data points lie mainlv in quadrants $I I$ and $\mathrm{V}$.

The line labeled $\mathrm{R}_{2}$ is the regression line relating the percent changes in the real trade-weighted exchange ate associated with the changes in the expected real interest rate differemial. It should slope upward from left to right: instead, it slopes downward, suggesting that an increase (decrease) in the real interest late diferential is associated with a decrease increase in the real exchange late. This estimated inverse relationship, however, is not a statistically significant one: that is, the clam that there is no simple linear relationship between these variables cannot be rejected at standard statistical significance levels. This puzzling result again suggests that deciphering the effect of changes in real interest rate differentials on exchange rate movements aquires detailed and careful econometric analysis.

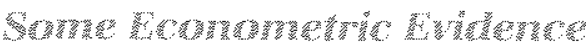

Empirical studies of real exchange rates and real interest difenentials offer a somewhat qualified view of their relationship. For example, one recent investigalion of the issue found a small statistically significant lagged response of the real exchange rate to the real

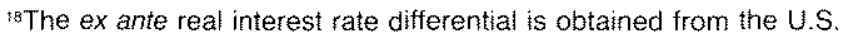
three- and four-month money market interest rate minus the tradeweighted average three- and four-month money market rates for six industratized countries adjusted by corresponding Organization for Economic Cooperation and Development (OECD) inflation forecasts.
} 
Char: 4

\section{Real Trade-weighted Exchange Rate and Real Interest Rate Differential}

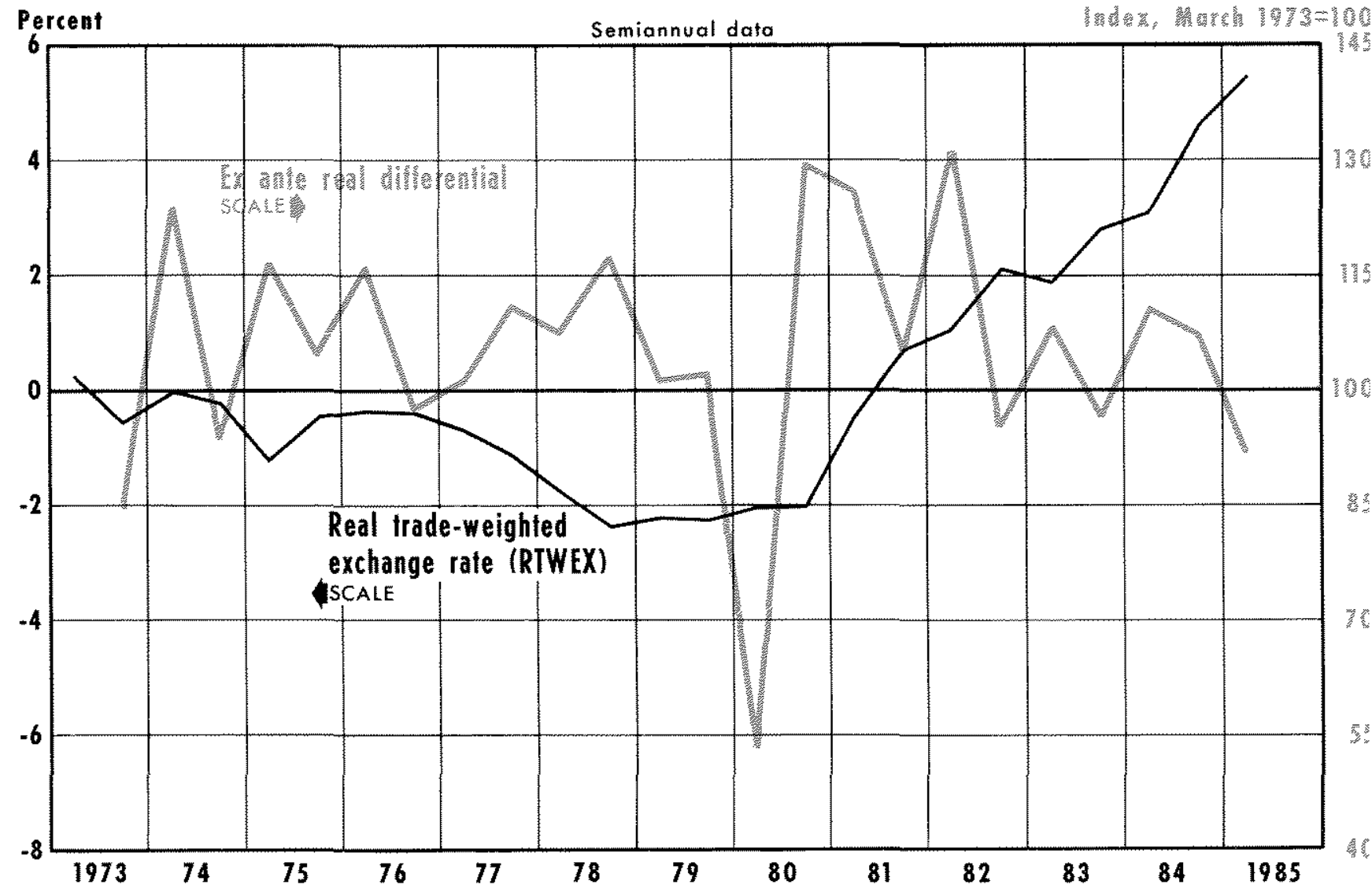

interest rate diferential." Specifically the study fou that a 10 -basis point change in the U.S. minus forei real interest differential would cause after two qua ters, a 0.23 percent rise in the real value of the dollar. This study atso found no independent effect of deficits on the real exchange rate." In general it appears that we know very litle about the extent to which reat interest rate differentials actually affect real exchange rates.

\footnotetext{
Batten and Belongia (forthcoming 1986).

The estimated coefficients from this type of statistical study are strictly valid only for small changes in variables. Therefore, the example presented should not be expanded to conjecture, for example, that a 100 -basis-point change in the interest differential would cause a 2.3 percent change in the dolar's real value.

2. Similar resuits were found by Bisignano (1985)
}

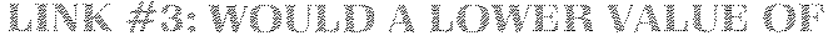

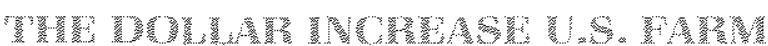

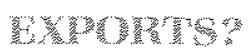

Farmers and legislators would like to increase th real value of U.S. farm expots. Would lower exchang rates result in a significant increase in real fam exports?

We discussed earlier how exports could be affecter by changes in the exchange rate. Puchasing powe parity conditions suggest that movements in ex change rates should exactly offset changes in the pric of the same commodity in different countries follow ing some adiusment period. For example, the price o coln should be the same actoss countries after adiust ments are made for exchange tate differences ane costs of mansportation. 


\section{Chart 5}

\section{Growth of Real Trade-weighted Exchange Rate and Change in Real Interest Rate Differential}

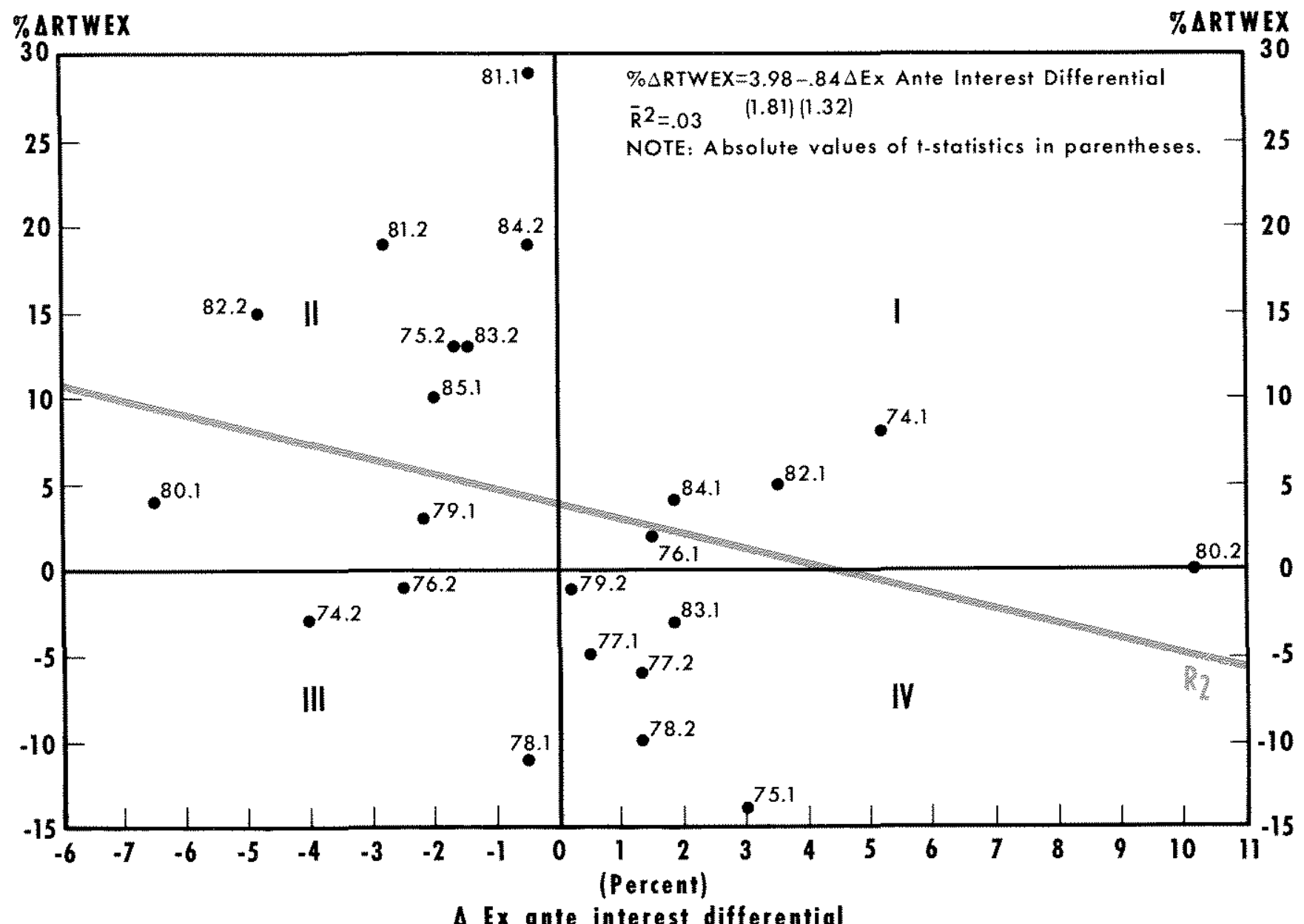

$\Delta$ Ex ante interest differential

There is substantial evidence, however, that pur' chasing power parity does nof necessarily hold in the short-run and that a considesable period of lime. perhaps as long as five to 10 vears, may be required before it finaly is reached. If this is the case, devations from purchasing power parity characterized by changes in the real exchange rate, nay have persistent and significant effects on real lam exports.

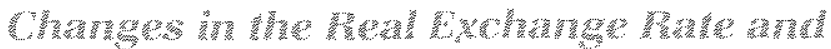

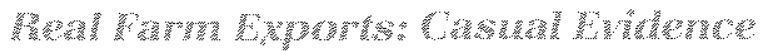

Chat 6 displays the behavion of the real exchange fate and real farm exports since 1973. Depending upon the specific vears chosen, a perusal of the chart vields both confiming and contradictorv evidence for the plesumed inverse relationship between movements in the exchange rate and fam exports. For example, exchange lates and farm exports noved in opposite directions from 1976 to the first half of 1979 , in 1982, and from the second half of 1984 to the hist half of 1985 . However, exchange tates and farn exports moved genemaly in the same direction from 1973 to the first half of 1976 and from 1979 to 1980 ; moreoves: fam exports remained vintualy unchanged from 1980 to the first hall of 1982 , and from the second hat of 1982 through 1984 , two periods when exchange iates were rising dramatically. 
Chart 6

\section{Real Trade-weighted Exchange Rate and Real Farm Exports}

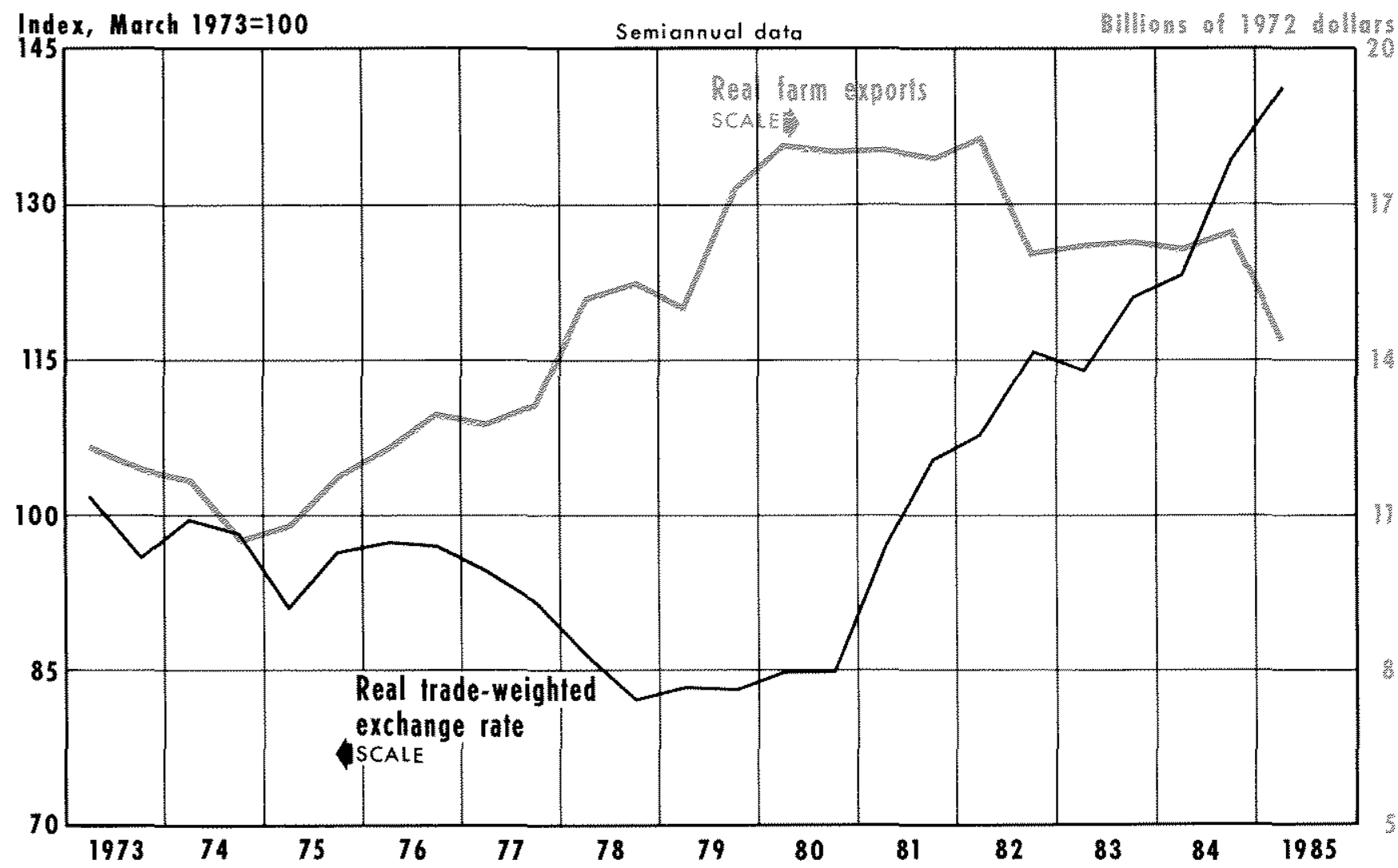

Chart 7 displays a scatter-diagram of changes in the real exchange rate and associated changes in real farm exports since 1973. Other things unchanged, economic theory predicts that the points should lie predominantly in the second III and fourth (IV) quadlants; positive negative changes in the real exchange late should be associated with negative (positive) changes in real farm exports. This, however, is not the case: the data points are randomlv scattered throughout the four quadrants and nealy half of them lie in the wrong ones.

The line labeled $\mathrm{R}_{\mathrm{i}}$ is the regression line relating the percent changes in real farm exports associated with the percent changes in the real exchange rate. It should slope downward from left to right and it does. The negative slope, however, is not statistically significant. Thus, the possibility that there is no contemporaneous relationship between changes in the exchange rate and lam exports cannot be rejected.

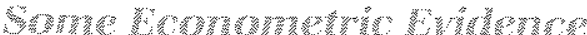

Empirical studies have shown that changes in the real exchange rate do affect imports and exports over a considerable time period. When these longer-1un effects are taken into account, movements in the real exchange rate have the expected effects on imports and exports. A summary of selected studies examining the long-run impact of changes in the real exchange rate on the demand for U.S. merchandise exports and imports is shown in table 2." Merchandise exports consist of all products. including farm products, exported to the rest of the world; the "longr-run price elasticity of export demand is the total percentage change in export volume in response to a sustained 1 percent change in the relative price of U.S. exports to

\footnotetext{
zSee Congress (1985b), p. 49.
} 


\section{Chart 7 \\ Growth of Real Trade-weighted Exchange Rate and Real Farm Exports}

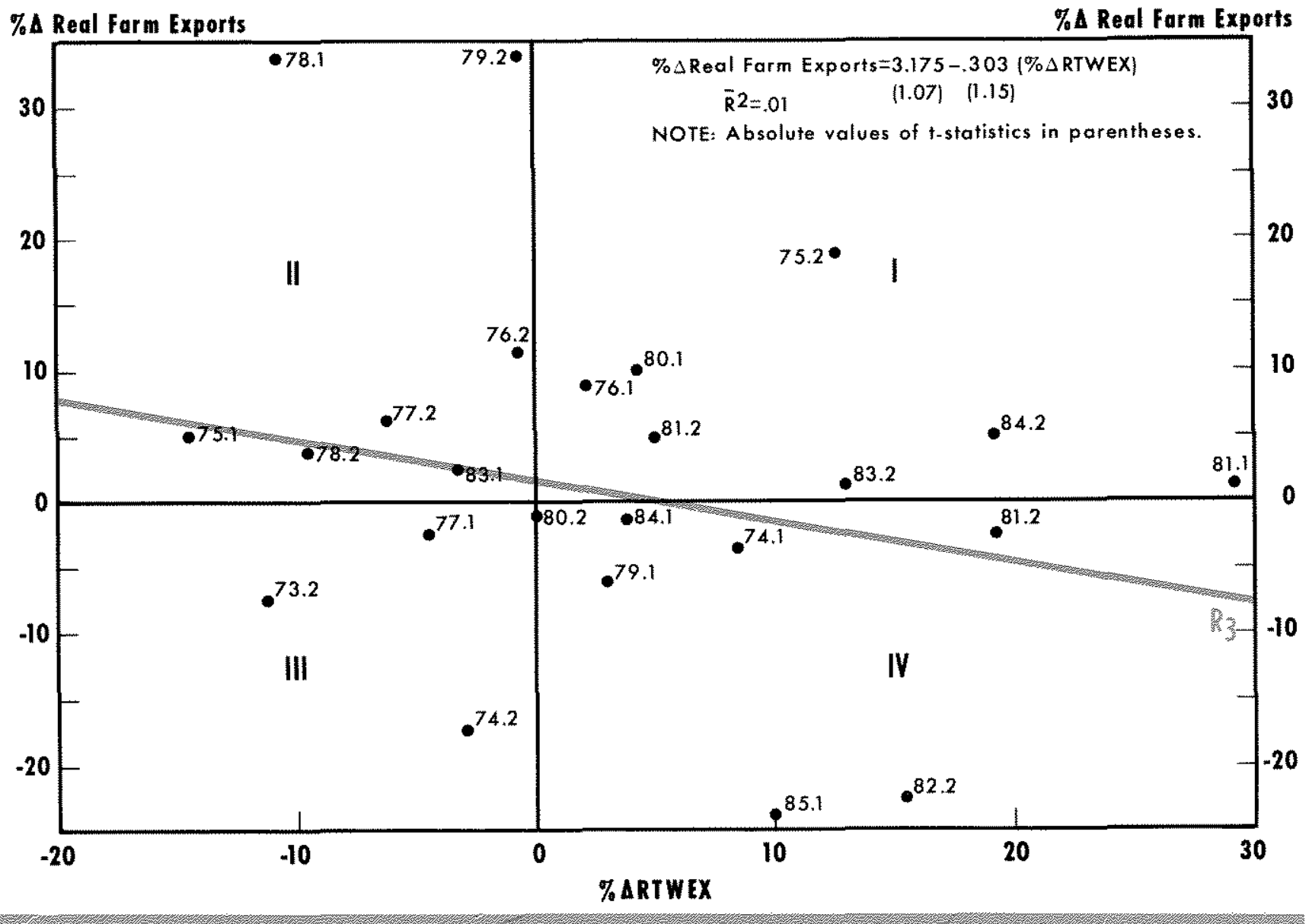

foreigners, after it has had time to adjust fully." The elasticities are all negative as expected. Although the estimated elasticities range from -0.3 to -2.3 , the more recent ones run close to -1 , indicating that a 1 percent drop in the real exchange rate will, after sufficient time passes, induce a 1 percent rise in total merchandise exports.

Two recent studies focused specifically on the effect of changes in the exchange rate on agricultural exports. After estimating a simple quarterly reducedform equation for the real value of farm exports, the find that a 1 percent fall in the real value of the dolla ${ }^{2}$

${ }^{23}$ See Congress (1985b), p. 48.

${ }_{24}^{24}$ atten and Belongia (1984, forthcoming 1986). will increase the real value of fam exports by 0.7 percent within one and one-quater vears. Thus, unlike the previous two links, the third link in the chain running from deficits to fam exports has both theoretical and empirical support.

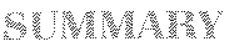

There is a widely shared view that federal deficits have contributed significantly to higher nominal and real interest rates in the United States. Moreover, it is commonly believed that these higher rates have contributed significantly to the rising foreign exchange

${ }^{25}$ Batten and Belongia (forthcoming 1986) 
Table 2

\section{Long-Run Price Elasticities of Demand for U.S. Merchandise Exports and Imports}

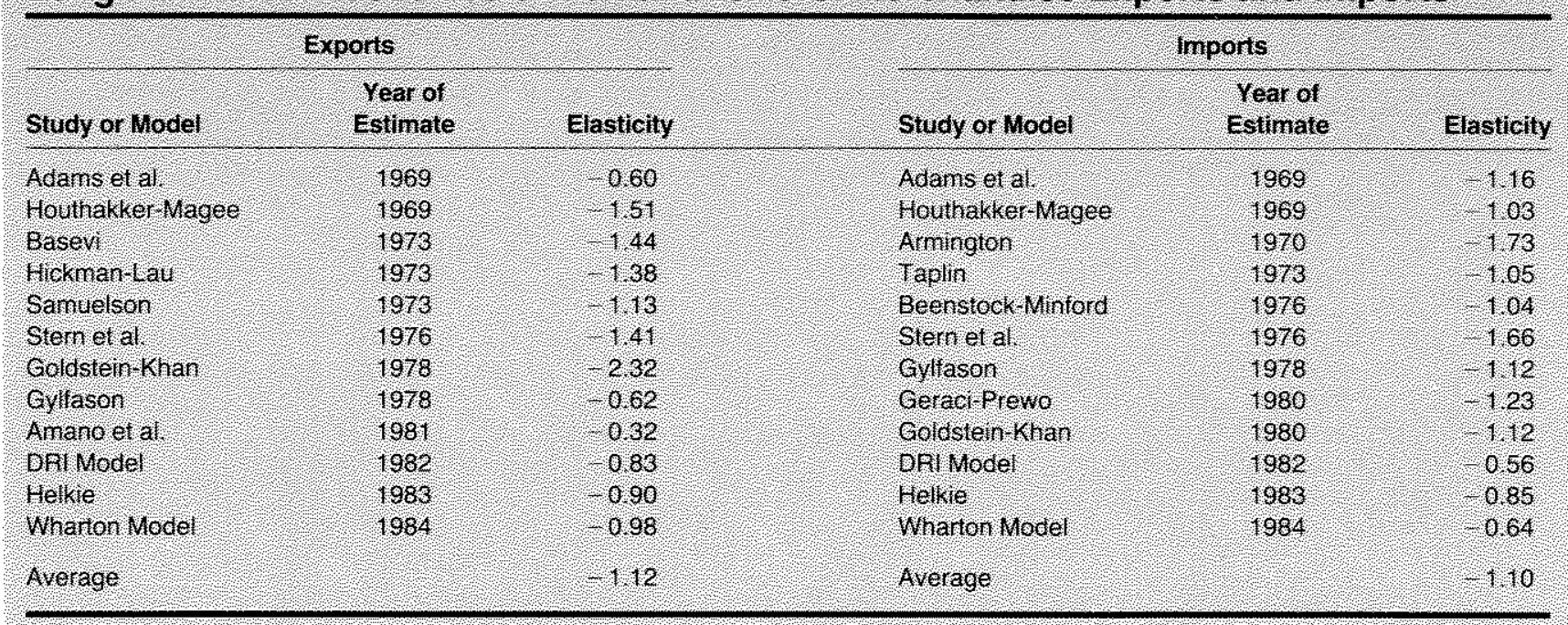

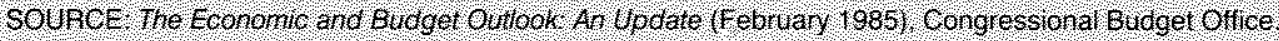

value of the dollar. Thus, it frequently is argued that our nation's exporting sectors, producers of farm commodities in particular, will continue to suffer until federal deficits are reduced and U.S. interest rates are brought down.

In this article, we examined three vital links in the conventional argument that ties the defieit to farm exports. With respect to the first link. we noted that there is considerable theoretical controversy ove: whether larger deficits actually cause real interest rates to increase. We found little empirical evidence to support this view.

Second, we noted that even if lower deficits did result in lower U.S. real interest rates, thev would not necessarily have a salutary impact on the real exchange rate. Apparently, other influences on the real exchange rate have offset the effect, if any, of changes in real interest rate differentials in recent vears. Among these other factors may be "the strong pertormance of the U.S. economy, confidence in the strength and stability of the political svstem in the United States, capital flight from deblor countries, [and a substantial shift in the extemal position of American banks." "The important point is that there is little

2epöhl(1985). Similar comments have been made by a wide variety of commentators: e.g." "At various times, other factors, which are difficult to measure, have also influenced the dollar ... The reversai empirical evidence to show that changes in the real interest rate differential have had a signiticant impact on movements in the real exchange rate during the past 13 vears.

Finally, we showed that, although US. farm exports are inversely related to the real exchange value of the dollar, the demand relationship is inelastic and $\mathrm{ex}$ change ate movements have their full effect only over a considerable time period. However, even though lower exchange rates would over time, increase U.S. farm exports, the failure of the first two links to be supported saggests that we cannot necessarilv expect that lower deficits will result in a lower value of the dollar in toreign exchange makets."

None of the discussion above should be taken as evidence that deficits per se are either good or harmless. Nor does it prove that layger deficits have had no adverse effect on real interest rates, on the foreign exchange value of the dollar or on farm exports. Unfortunately, at the present time, there continues to be

in the dollar's fortunes since late 1980 may bel related to (i) the election of a new administration committed to a more conservative approach to financial policies; and (ii) the increased risks associated with other curtencies." Atkinson et al. (1985), pp. 37 and 39

2: See Poole (1985) for a discussion of why lower budget deficits might be expected to raise the value of the dollar. 
considerable uncertainty aboul the effects that larger deficits actually have had on these key economic variables."*

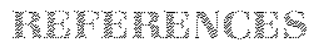

Atkinson, P. A. Blundell-Wignall, J., C. Chouragui, and G. Hacche. Exchange Rate Management and the Conduct of Monetary Poilcy, OECD Monetary Studies Series, OECD (1985).

Barro, Robert J. "Are Government Bonds Nel Wealth?" Joumal of Political Economy (November:December 1974), pp. 1095-117.

Batten, Dallas S., and Michael T. Belongia. "The Recent Decline in Agriculturat Exports: Is the Exchange Rate the Culprt?" this Review (October 1984), pp. 5-14.

"Monetary Policy, Real Exchange Rates and U.S. AgriCultural Exports," American Joumal of Agricultural Economics, fortheoming (May 1986)

Bisignano, Joseph. "Fiscal Deficits and Exchange Rates: A Look at Recent Policy Assertions and Their Theoretical and Empirical Support," Working Paper 85-04, Federal Reserve Bank of San Francisco (dune 1985)

Brown, W. W., and G. J. Santoni. "Unreal Estimates of the Real Rate of Interest," this Review (January 1981), pp. 18-26.

Clark, Lindley H., Jr. "On the Beach In Bermuda With a Book," Wall Street Journal, October 29, 1985.

Congressional Budget Office. The Economic Outook, Congress of the United States (Government Printing Otice, February 1984).

The Economic and Budget Outook: Fiscal Years 19861990 (GPO, February 1985a).

August $\$ 985 \mathrm{~b}$ )

The Economic and Budget Outlook: An Update (GPO

Dobson, William D. "Effects of the Macroeconomic Environment on 1985 Farm Legislation," in United States Department of Agriculture, Outlook 1985; proceedings of the Agricutural Outlook Conference, December 3-5, 1984, pp. 48-58

Downs, Anthony. "This Bulding Boom Shows Something's Busted," Wall Street Joumal, October 29, 1985.

Duncan, Marvin, and Mark Drabenstott. "Economic Scene," New York Times, August 16, 1985.

Holland, Steven, A. "Real Interest Rates: What Accounts for Their Recent Rise?" this Review (December 1984), pp. 18-28.

29For additional discussion and empirical evidence supporting this conclusion, see Bisignano (1985) and Wallis (1985). Even Dobson, whose diagram of the deficit's effects on the economy appears in figure 1 , notes that "how much the federal deficits infuence the variables in the diagram is not known with much certainty. "Dobson, $(1984)$, p. 49.
Isard, Peter. "Factors Determining Exchange Rates: the Roles of Relative Price Levels, Balances of Payments, Interest Rates and Risk," Federal Reserve Board, International Finance Discussion Papers, Number 171 (December 1980).

Kormendi, Roger C. "Government Debt, Government Spending and Private Sector Behavior," American Economic Review (December 1983), pp. 994-1010.

Kraft, Joseph. "Weird Economics, Bizarre Politics," Washington Post, October 27, 1985.

Malabre, Alfred L., Jr. "Whither the Deficit When Recession Arrives," Wall Street Joumal, September 20, 1985.

Modigliani, Franco. "And Why the Deficit Must Be Slashed," New York Times, November 3,1985

Pöh, Karl Otto. Address to the international Industrial Conference (September 19.1985), reproduced in Bank for International Settlements, Press Review (September 20, 1985)

Poniachek, Harvey. A. "The Determination of Exchange Rates," in Abraham M. George and lan H. Giddy, eds., international Finance Handbook, Volume 1 (Wiley, 1983), pp. 2.3.3-2.3.44.

Poole, William. "Summary Comments," speech delivered at the Federal Reserve Bank of Kansas City Conterence, Jackson Hole, Wyoming. August 23, 1985

Protopapadakis, Aris A., and Jeremy J. Siegel. "Government Debł, the Money Supply, and Inflation: Theory and Evidence for Seven Industrialized Economies," Working Paper No. 84-4, Federal Reserve Bark of Phitadelphia (August 1984).

Rasche, Robert H. "Views on Deficits and Interes: Rates," Federal Reserve Bank of San Francisco Weekly Letter (April 19, 1985).

Santoni, G. J., and Courtenay C. Stone. "Navigating Through the Interest Rate Morass: Some Basic Principles," this Review (March 1981a), pp. 11-18.

"What Really Happened to Interest Rates? A Longer Run Analysis," this Review (November 1981b), pp. 3-14.

"The Fed and the Real Rate of Interest," this Review (December 1982), pp. 8-18.

Schuh. G. Edward. "Future Directions for Food and Agricultural Trade Policy:" American Joumal of Agricutural Economics (May 1984), pp. $242-47$

Seater, John J. "Are Future Taxes Discounted?" Joumal of Money, Credit and Banking (August 1982), pp. 376-89.

Tatom, John A. "A Perspective on the Federal Deficit Problem," this Review (June/July 1984), pp. 5-17.

"Two Views of the Effects of Government Budget Deficits in the 1980s." this Review (October 1985).

U.S. Department of the Treasury. "The Effects of Deficits on Prices of Financial Assets: Theory and Evidence," (GPO, 1984).

Wallis, Allen. "On Deficits and Interest Rates," Washington Post, November 4, 1985

Weintratb, Roben $E$. "Deficits: Their Impact on Intlation and Growth," Staff Study for the Subcommittee on Monetary and Fiscal Policy of the Joint Economic Committee $(\mathrm{GPO}$, July 30,1981 ). 